\title{
ステレオビジョンを用いた車両横すべり角の計測*
}

\author{
松 井 俊 樹*1, 菅 沼 直 樹*2, 藤 原 直 史*2

\section{Measurement of Vehicle Sideslip Angle Using Stereovision} \\ Toshiki MATSUI*3, Naoki SUGANUMA and Naofumi FUJIWARA \\ ${ }^{* 3}$ Graduate School of Natural Science \& Technology, Kanazawa University, \\ Kakuma-machi, Kanazawa-shi, Ishikawa, 920-1192 Japan

\begin{abstract}
In this paper, we describe about the measurement technique of vehicle sideslip angle using stereovision system. The vehicle sideslip angle is one of the vehicle state quantities. Moreover, this parameter is very important for control system of vehicles such as the dynamics stability control system. We propose measurement technique for sideslip angle using stereovision system. This technique uses the disparity and the optical flow to measure the relative movement of the vehicle. Moreover, it only uses two cameras, PC and the rate gyro. So, this measurement system can be realized inexpensive. Additionally, we propose using the predicted image based on vehicle motion model, in optical flow analysis. The result of the optical flow analysis has been improved by proposal method. It is confirmed that proposed technique can measure the movement distance and the sideslip angle by the experiment.
\end{abstract}

Key Words : Image Processing, Measurement, Automobile, Stereovision, Sideslip Angle, Prediction Image

\section{1. はじめに}

近年, 交通事故の増加や都市部における道路渋滞な どの問題に対し, 道路交通の知能化・情報化て解決を 図る高度道路交通システム(IIS)に関する研究が幅広く 行われているい.この中には, 運転支援・自動運転を 行う制御システムに関する研究が多く存在する. 実際 にこれらを使用する際には, 車両の走行姿勢を示す状 態量が必要となる. 車両横すべり角はそのうちの一つ であり, 車体の向きと速度ベクトルのなす角として求 められ，制御性能を左右する重要なパラメータである Ð. ただし，一般的に車両横すべり角の計測は非常に 難しいとされているす.

車両横すべり角の検出手法は, 対地速度を外界セン サにより計測して解析する手法(けと, ステアリング 舵角やレートジャイロなどの内界センサおよび車両の 運動モデルからオブザーバにより推定する手法の,(た 大別される. 前者は高精度な計測が可能であるが, こ れまでに提案されているものは光学式などの対地速度 センサや RTK-GPS などの特殊なセンサを使用してい るため, 非常に高価となり一般的ではない. また, 後 者においては安価に実現できるものの, 路面状態や乗 車人数の変化がコーナリングパワーに影響を与え, 推

\footnotetext{
* 原稿受付 2005 年 1 月 18 日.

*1 准員, 金沢大学大学院自然科学研究科( $\mathbf{W} 920-1192$ 金沢书 角間町)。

*2 正員, 金沢大学大学院自然科学研究科.

E-mail : toshi@puma.ms.t.kanazawa-u.ac.jp
}

定精度が変化することが報告されているき. 我々は, パラメー夕変動に影響されない前者による解析手法に 注目し，これを安価なセンサにより実現することを目 標とした. 本報では，近年普及しつつある前方注視用 のステレオビジョンのにより車両の移動量を解析し, 車両横すべり角を計測する手法を提案する. 具体的に は, 視差による 3 次元位置計測とオプティカルフロー 解析により車両の移動量を解析するものである. また, 自車両の運動が大きくても車両状態量と運動の幾何学 モデルから隣接する時刻の画像を予測することで, 対 応点の探索範囲を拡大することなくオプティカルフロ 一を解析する手法を提案する. なお, この計測手法で 使用するのはカメラ 2 台, 演算装置となる沉用 PC お よびレートジャイロのみであるため, 比較的安価に実 現できる. 最後に, 提案手法の有効性を光学式すべり 角センサとの比較実験により検証した.

\section{2. 画像による迋称解析}

図 1 に, 微小時間 $\Delta t$ 内に車両がヨーレート $\gamma$ ，車速 $v$, 車両横すべり角 $\beta$ で走行した場合の車両運動の幾何 学モデルを示す. このとき, $\beta$ は車両回転角 $\theta$ 之並進移 動量 $t_{x}, t_{y}$ から

$$
\beta=\tan ^{-1} \frac{t_{y}}{t_{x}}-\frac{\theta}{2}
$$




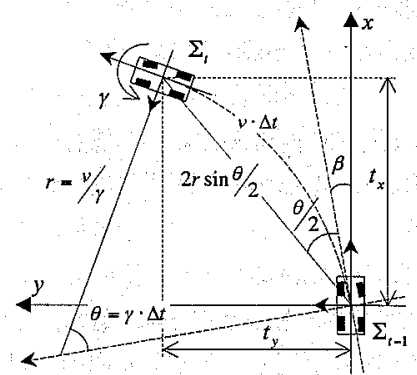

Fig.1 Geometrical model of vehicle movement

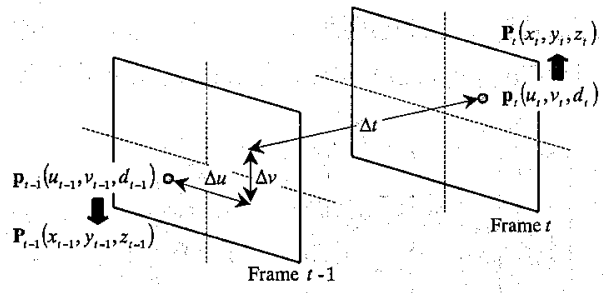

Fig.2 Existing technique of movement analysis

と計算することができる. 式中の車両回転角 $\theta$ はジヤ イロの計測值から $\theta=\gamma \cdot \Delta t$ 之求めることができる、よ って，車両横すべり角計測のためには並進移動量を計 測することが必要となる. 本報では，この車両並進移 動量をステレオビジョンにより計測し，その結果から 車両横すべり角を求める.

2.1 画像による運動解析手法 まず，画像全体 の各画素において, 視差とオプティカルフローにより フレーム間における 3 次元での動きを解析する. 視差 とオプティカルフローを使用した周辺環境の運動解析 手法は，加賀美らによって提案されている10。.これは 図2に示すように，各時刻における画像で視差と才プ ティカルフローを解析し，これらの情報からフレーム 間における運動解析を行うものである. 任意の点 $\mathrm{p}_{t-1}$ において, 画像座標 $\left(u_{t-1}, v_{t-1}\right)$ 之視差 $d_{t-1}$ から 3 次元位置 $\left(x_{t-1}, y_{t-1}, z_{t-1}\right)$ が解析できる. また，オプティカルフロ 一により，対応点 $\mathrm{p}_{t}$ を求めることがでさる.この対応 点の 3 次元位置 $\left(x_{t}, y_{t}, z_{t}\right)$ も同様に画像座標 $\left(u_{t}, v_{t}\right)$ と視 差致から解析することができる。これにより，フレー ム間での各点における移動量を求めることができる.

22 視差とオプティカルフローの解析 次に, 視差とオプティカルフローの解析方法について述べる. これらの解析手法は柱に，特徵点ベースの手法之領域 ベースの手法に分類される(1). 一般的な特徴点ベース の解析手法では，濃淡エッ濰の特徽を抽出してこれ らの特徵点に対してのみ対応関係を求めるため, 疎な 結果か得られる. 対して領域べースの解析手法では, 特に解析対象を限定せすにに濃度パターンから対応点の 探索を行うため, 特徵点ベースの解析手法に比べて密
な結果が得られる，我々は，運動解析を路面などの絶 対的に静止している領域に対して行うことにより，自 車両の運動を解析することとしている。つまり，解析 対象の大半が特徴量の乏しい領域である。このことを 考慮すると，特徴点べースの解析手法では計測に失敗 する可能性が高くなる. そこで，領域べースの解析手 法であるブロックマッチングを採用し，評価関数には SAD(Sum of Absolute Difference)を採用した さらに, 左右 画像や時系列画像を解析する際に発生する輝度差を抑 えるために，マッチングの前処理として LoG フィル 夕を適応した 以上の処理により得られた視差解析結 果を図 3 に示す．輝度が高いほど視差が大きく，距離 が近いことを示している. なお，虫食いの部分はマッ チングに失敗し，視差が得られなからた部分である. これに対し、オプティカルフローの解析においてはい くつかの問題方発生した。この問題こついて, 図を用 いて詳しく説明する.

車両が走行した場合に得られる隣接した時刻にお ける画像の模式図を図 4に示す. $t-1$ フレームにおいて, マッチングを行うためのテンプレートブロック $\mathrm{A} \sim \mathrm{C}$ が与えられているとする.このとき， たレームにお いて，探索領域は $\mathrm{a} \sim \mathrm{c}$ で設定される，この条件でマ ッチングを行った場合, ブロック A は位置a'と一致す ることとなり問題は発生しない，次に，一定間隔で設 置されているラバーポール等を含んだブロック B に ついて考えてみる. 本来ならば，対応点 b”と対応す るはずが,この場合では探索領域に入ってきた一つ先 のラバーポールの位置 $\mathrm{b}$ とマッチングしてしまう. ま たフブロック Cにいたっては対応点 c”が探索領域に 存在しないことにより,マッチングに失敗してしまう

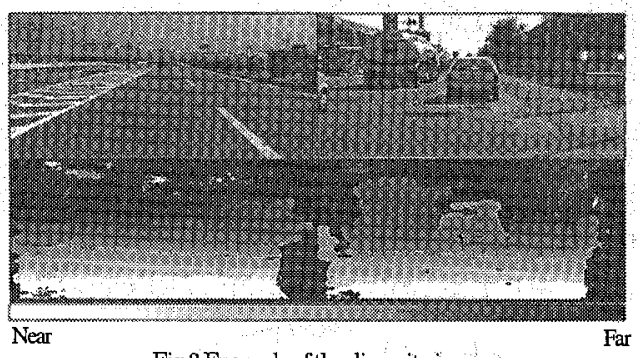

Fig.3 Example of the disparity image

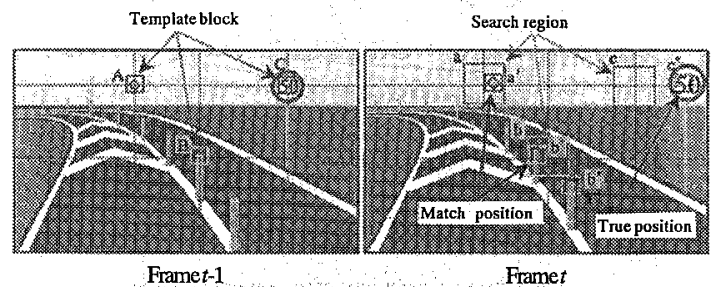

Fig.4 Example of time series images 
ことになる. ブロック C のような場合には，探索領 域を拡大することによりある程度対応可能である. し かし, ブロック B のようなケースには対応できない 点と, 処理時間が増加してしまう点から好ましくない. この問題の原因となるのは自車両の運動であり, 高速 で運動した場合などにはより顕著にその影響か現れて くる. ただし, 自車両の運動は図 1 で示す幾何学モデ ルで表すことができ，必要な状態量もセンサにより計 測することが可能である. 我々はこの点に注目し，視 差解析結果と幾何学モデル，および各種車両状態量か ら隣接する時刻での予測画像を作成し，この画像を使 用して運動解析を行う手法を3章で提案する.

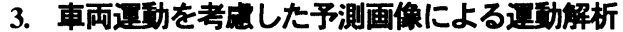

本章では，我々が提案する予測画像による運動解 析手法について説明する. 3.1 では，提案する予測画 像を使用した移動量解析手法の流れを述べ，32では 3 次元位置解析結果之車両運動の幾何学モデルから, 隣 接した時刻の画像における画素の運動を予測する手法 について述べる. 最後に，33 では解析結果を基にし た車両横すべり角の推定手法について述べる.

3.1 予測画像を使用した更劧解析 まず, 予測 画像を使用した運動解析手法について述べる. すでに 時刻 $t$ と $t$-1における視差画像は解析済みであるとする. まず, 任意点の時刻 $t$ における 3 次元座標 $\mathbf{P}_{t}\left(x_{t}, y_{t}, z_{t}\right)$ は視差と画像座標から求めることができる. 次に, 32 で述べる手法により隣接する時刻における移動先 $\mathbf{P}_{p}\left(x_{p}, y_{p}, z_{p}\right)$ を全画素について予測し, 予測画像を作 成する(図 5(1). ただし，これは運動モデルにより予 測したものであり, 本来の画像に対してモデル誤差や センサ誤差などの影響を含んでいる. そこで, 予測画 像と $t-1$ の画像間でフロー解析を行い，このズレを求 める(図 5(2). つまり, 車両運動による大変動を幾何 学モデルにより吸収し, 残る誤差やその他の影響によ る小変動をフローにより吸収するというアプローチで ある. これにより, 予測座標 $P_{p}$ に対応する 3 次元座 標 $\mathbf{P}_{t-1}\left(x_{t-1}, y_{t-1}, z_{t-1}\right)$ を求めることができ, 最終的には $\mathbf{P}_{t}$ と $\mathbf{P}_{p}$, そして $\mathbf{P}_{t-1}$ の位置関係を用いて図 5(3)ように

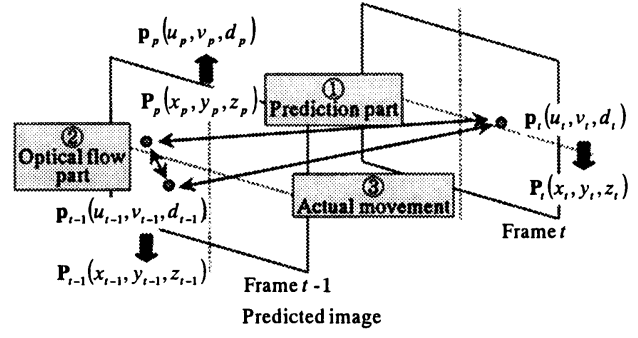

Fig.5 Proposal technique of movement analysis
本来の対応関係を求めることが可能となる.

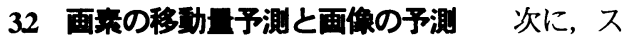
テレオ視による 3 次元位置解析結果と車両状態量によ り，隣接した時刻の画像間において任意の画素がどの ような位置関係にあるかの予測手法について述べる。

まず，時刻 $t, t-1$ における視差が解析済みであり， それぞれの時刻におけるカメラと道路面との幾何学関 係が解析できているものとするは。，なお，この幾何学 関係から車両運動が図 1 に示す平面運動で記述できる よう位置解析結果を補正している，各時刻における車 両座標系 $\Sigma_{t-1}, \Sigma_{t}$ から観測した同一点の 3 次元座標を それぞれ $\left(x_{t-1}, y_{t-1}, z_{t-1}\right)$ ，および $\left(x_{t}, y_{t}, z_{t}\right)$ と仮定すると，

$$
\left(\begin{array}{c}
x_{t-1} \\
y_{t-1} \\
z_{t-1} \\
1
\end{array}\right)=\left(\begin{array}{cccc}
\cos \theta & -\sin \theta & 0 & t_{x} \\
\sin \theta & \cos \theta & 0 & t_{y} \\
0 & 0 & 1 & 0 \\
0 & 0 & 0 & 1
\end{array}\right)\left(\begin{array}{c}
x_{t} \\
y_{t} \\
z_{t} \\
1
\end{array}\right) \ldots \ldots . . .(2)
$$

という関係が成立する. ここで, $t_{x}, t_{y}$ は図 1 の幾何学 モデルから

$$
\left\{\begin{array}{l}
t_{x}=2 v / \gamma \sin \theta / 2 \cdot \cos (\theta / 2+\beta) \\
t_{y}=2 v / \gamma \sin \theta / 2 \cdot \sin (\theta / 2+\beta)
\end{array}\right.
$$

と計算できる．ここで, 未知のパラメータである車両 横すべり角陪ま含まてていが $\theta / 2$ に対して十分小さ い点，予測された移動量は誤差を含んでいることを 仮定している点から $\beta=0$ とする，なお，それぞれの 画素における 3 次元位置は視差画像から求めることが でき,これらの計算を画像全体において行うことで, 予測画像が作成できる．ただし，遠方では位置解析の 信頼性が低いため，予測は行わないこととした。

求めた移動量予測結果を利用して予測画像を作成す る前に, どちらの時刻における予測画像を作成するか について考える. まず，図6に予測画像の例を示す. 中段に示す画像が予測対象となる画像であり，上段が 前の時刻の画像から予測したもの $\left(\Sigma_{t} \Rightarrow \Sigma_{t-1}\right)$, 下段が 先の時刻から予測したもの $\left(\Sigma_{t-1} \Rightarrow \Sigma_{t}\right)$ である. なお, 右列はそれぞれの画像の一部を拡大表示したものであ る. 走行状態において, 自車両は前進している場合が 大半であることを考慮すると, 前の時刻から画像を予 測することで，下段のように広い範囲で画素の移動を 予測することができ，利用できる情報量が増える．し かし，これは画像を拡大することと等価であり, 中段 の対象画像に対して画像がぼやけてテクスチャが減少 


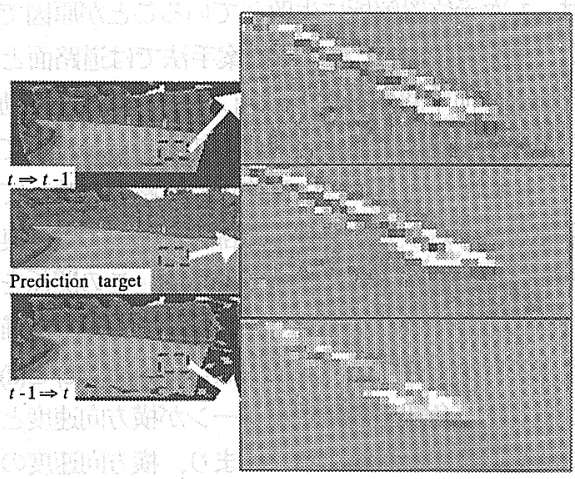

Fig.6 Example of prediction image

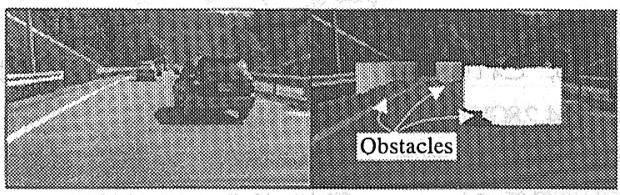

Fig.7 Example of obstacle detection

する，エッジ部における情報があいまいになるといつ た不具合が発生していることが右列の画像から確認で きる.これに対して先の時刻から画像を予測する場合 は，上段のように予測可能な画素数は減るが，ぼけは 少なくマッチングに対してさほど大きな不具合は発生 しないことか確認できる. よって，後者による予測を おこなうこととした.

これとは別に，画像変換を行わずに予測された移動 画素周辺において探索領域を設定し，フロ一解析を行 う手法が考えられる。この手法は，画像変換を必要と しない利点を持つが，画像内での回転や拡大・縮小と いった “見え”の変化への対応が困難である．これは， 移動量が大きい場合や近距離の領域においてより顕著 にあらわれる. 我々は，計測精度の高い近距離の領域 での計測が不安定になることを大きなデメリットと考 え，予測画像による解析手法を採用することとした.

33 車両横すべり角の計測 前節までの手順で 各画素における 3次元位置の対応関係をそれぞれ求め ることができた．車再回転角の影響を除去した自車両 の並進量は，式(2)を変形した次式と図 1 に示した車両 回転角 $\theta$ から求めることができる.

$$
\left(\begin{array}{l}
t_{x} \\
t_{y}
\end{array}\right)=\left(\begin{array}{l}
x_{t-1} \\
y_{t-1}
\end{array}\right)-\left(\begin{array}{cc}
\cos \theta & -\sin \theta \\
\sin \theta & \cos \theta
\end{array}\right)\left(\begin{array}{l}
x_{t} \\
y_{t}
\end{array}\right)
$$

車両横すべり角は，この結果と式(1)から計算すること ができる，実際には，画像全体で式(4)により並進移動 量を計算して，ての結果をヒストグラム化する．その 後,ピーク值をその時刻における移動量として採用し
Table1 Specification of stereovision system

\begin{tabular}{|c|c|}
\hline Image sensor & $\begin{array}{c}1 / \text { inch } \\
\text { Progressive scan CCD }\end{array}$ \\
\hline Baseline length & $360[\mathrm{~mm}]$ \\
\hline Focal length & $6[\mathrm{~mm}]$ \\
\hline Image size & $320 \times 160$ [pixel] \\
\hline Base block size & $8 \times 8$ [pixe] \\
\hline Search block size (Dispanity) & $49 \times 8$ [pixel] \\
\hline Search block size(Optical flow) & $19 \times 19$ [pixel] \\
\hline
\end{tabular}

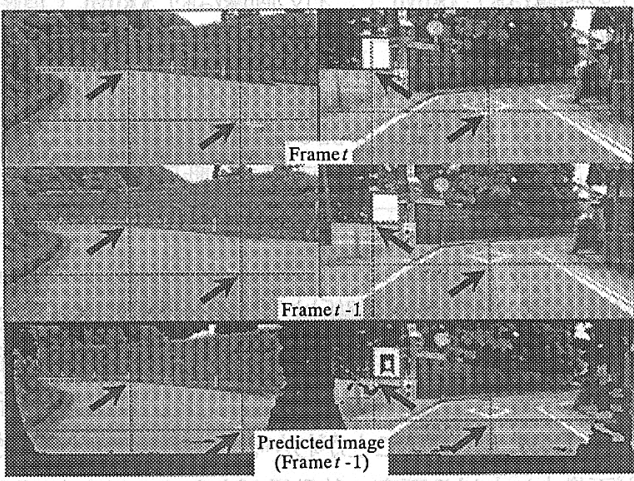

Fig.8 Example of prediction image

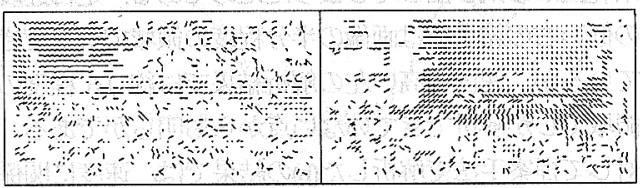

(a) Frame $t$ and frame $t$

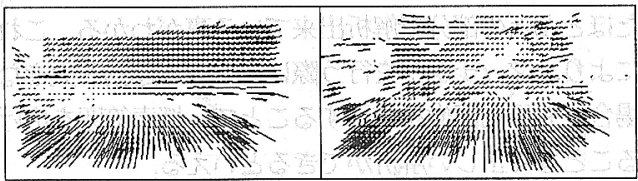

(b) Predicted image and frame $t-1$

Fig.9 Example of analyzed movement distance on image

ている. ただし，ヒストグラムに結果を投票する際に 先行車両などの自車両の運動とは関係のない部分が多 く含まれると，計測ミスが起こってしまう可能性が高 い，そこで，我々が前報で提案した障害物検出アルゴ リズムは2によりこのような可能性のある画素を決定し， その画素での結果は投票しないこととした. このアル ゴリズムによる障害物抽出例を図 7 に示す.

\section{4. 検証実験}

提案手法の有効性を確認するために，検証実験を行 った．使用した動画は，晴れの夕力に実験車両を一般 道と金沢大学構内の駐車場で走行して撮影したもので あり，オフラインで解析した. なお，表1に実験で使 用したステレオビジョンシステムの詳細を示す.

4.1 予測画像の作成と移動蜜解析 3.1 で述へ た手法て推定した画像を図 8 に示す。この際，使用し た速度は車速パルスから得られた速度であり，コーレ 
ートはシリコンセンシングシステムズジャパン社製 シリコン振動ジャイロ SGN-100-20 の出力を 12bitAD コ ンバータで測定したものを使用した. 上段が時刻 $t-1$ の画像, 中段は時刻 $t$ の画像, そして下段が予測画像 である. なお, 予測画像の虫食い領域は視差が計算で きなかった部分, 視差の信頼性が低い遠方部分である. 左の画像は約 $50 \mathrm{~km} /$ で, 右の画像は約 $30 \mathrm{~km} /$ で道路 に沿って走行中のシーンである. 図中には, 路面マー カや特徵となる部分に破線を引いてある. どちらにお いても提案手法により予測した画像は，ほぼ一致して いることがわかる. 次に, 画素の移動量解析結果を図 9 に示す. (a)は時刻 $t$ と $t$-1の画像から解析した結果, (b)は予測移動量と推定画像およひ時刻 $t$ - 9 画像から 解析した結果である. 解析は，それぞれ図 8 と同一の シーンで行った. まず, (a)の結果では, 遠方では解析 できているが，ある距離より近い部分で移動量が解析 できなくなっていることがわかる.これは，近距離ほ ど画像内における画素の移動量が大きく, 対応点が探 索範囲から飛び出してしまったためである. 走行速度 の低い右の結果では画像の半分程度の領域で解析でき ているが, 速度の高い左の解析結果では約 $1 / 6$ 程度の 領域でしか解析できていない点からも明らかである. 対して提案手法で解析した(b)の結果では, 速度に関係 なく左右両方の画像において, 画素の運動を予測でき たほとんどの部分で解析出来ている事がわかる. これ により,マッチングを行う際に自車両の運動が大きな 場合でも予測画像を使用することで, 探索範囲を広げ ることなく正しい解析ができるといえる.

4.2 移動目解析結果の比校 ここでは, 小野測 器社製 非接触車速計LC-761システム (以下: 光学 式センサ）の出力を 12biAD コンバータで計測した值 と提案手法により計測した移動量から求めた值につい て, 縦横方向の各速度と車両横すべり角について比較 を行う. 図10(a)に，この実験において走行した2つの 速度レンジの異なるコースを示す. 左側か駐車場で行 った低速域での結果, 右側が一般道で行った中速度域 の結果である. コース上の数字はその位置における時 刻を示している. (b)には縦方向速度, (c)には横方向速 度, そして(d)には車両横すべり角の計測結果を示す.

(b)の縦方向速度についてであるが, 提案手法により 計測された值は若干のばらつきはあるものの, 光学式 センサの值とよく一致している. 次に, (d)横方向速 度について考える. こちらもばらつきが見られるもの の, 光学式センサの計測值と一致している. ただし, 破線で囲んだように左図の 30 秒と 58 秒, 右図の 35 秒付近において大きな誤差を持っている.これについ
ては, 3 次元位置解析に失敗していることが原因であ った. 32 で述べたように, 提案手法では道路面とカ メラとの幾何学関係を解析し, フレーム間での運動を 平面運動で記述できるよう位置解析結果を補正してい る. この解析を行うには，画像中に道路面か映ってい る必要がある. 誤差が発生した部分においては, 奥行 き方向に道路面が十分に映っておらず，この関係を導 出することができなかった. これにより, 正しく補正 を行うことができずに計測に失敗していた. (c) と(d)か らは横すべり角誤差の発生パターンが横方向速度と非 常に似ていることがわかる. つまり, 横方向速度の計 測精度を向上させることで, 車両横すべり角計測のさ らなる精度向上を図ることができると考えられる.

なお，これら一連の処理を行うために必要な時間は， Pertium4 28GH，メモリ 512MB の汎用 PCで約 200msec 前後であった. 制御システムで使用することを考虑す ると, 最低でも $100 \mathrm{msec}$ 程度に抑える必要がある.

43 既存の计湘器との比校 前述したように既 存の計測機器として, 本報内で使用した光学式センサ や複数の RTK-GPS を使用したものが挙げられる. こ れらは高精度に計測が可能であるものの, 導入には数 百万円オーダのコストが必要となるため, 一般車両へ の搭載は現実的ではない，これに対して，提案する計 測手法で必要なコストは現状で数十万円オーダである が, 将来的には普及帯までコストを抑えることが可能 であると思われる. また, 障害物検出用などのステレ オビジョンをすでに導入している場合には，新たにセ ンサを追加する必要がないことも利点の一つとなる. ただし，天候や照度変化に対するロバスト性の検討， 計測精度の向上, 処理時間の短縮が今後の課題である.

\section{5. おわりに}

本論文では，前方注視用のステレオビジョンを用 いた車両横すべり角の計測手法について提案した. ま た，実環境下での実験を行うことで提案手法の有効性 を確認することができた. 最後に, 本論文の内容は以 下のようにまとめられる.

（1）比較的安価なステレオビジョンとヨーレートジャ イロにより, 自車両の移動量を解析して車両横す べり角を計測する手法を提案した.

（2）フロ一解析において, 自車両の運動が大きい場合 でも予測画像を使用するにより, 探索範囲を抁大 することなく移動量を解析する手法を提案した.

（3）実環境下において高精度に計測可能な既存センサ との比較を行い, 提案手法の有効性と現状での問 題点を確認した. 

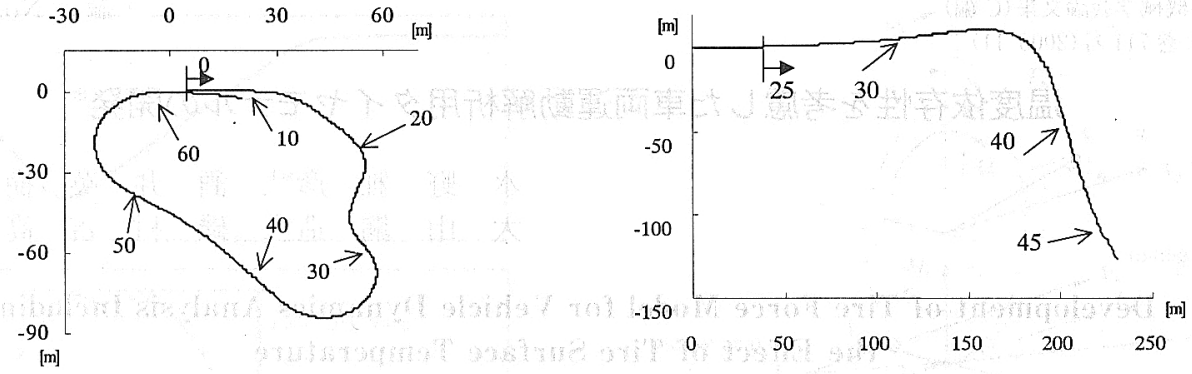

(a) Experiment course
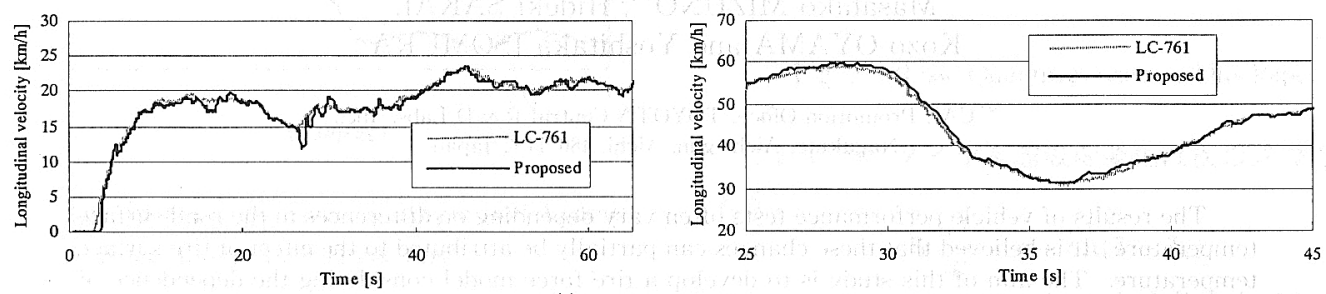

(b) Longitudinal velocity
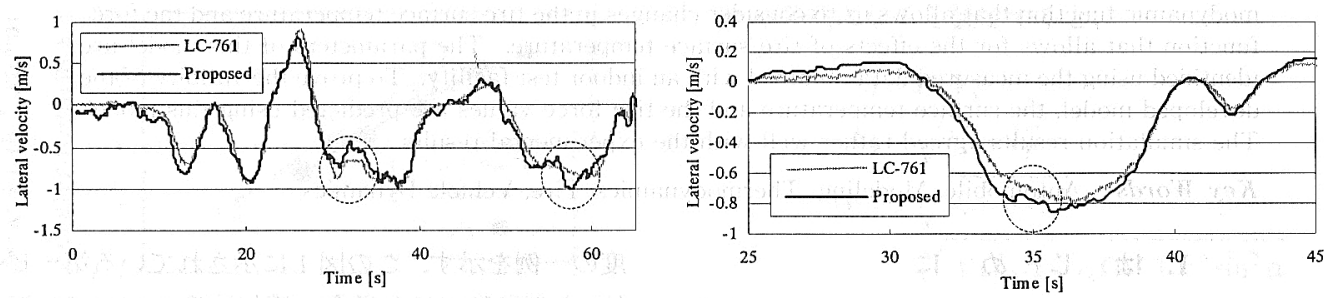

(c) Lateral velocity
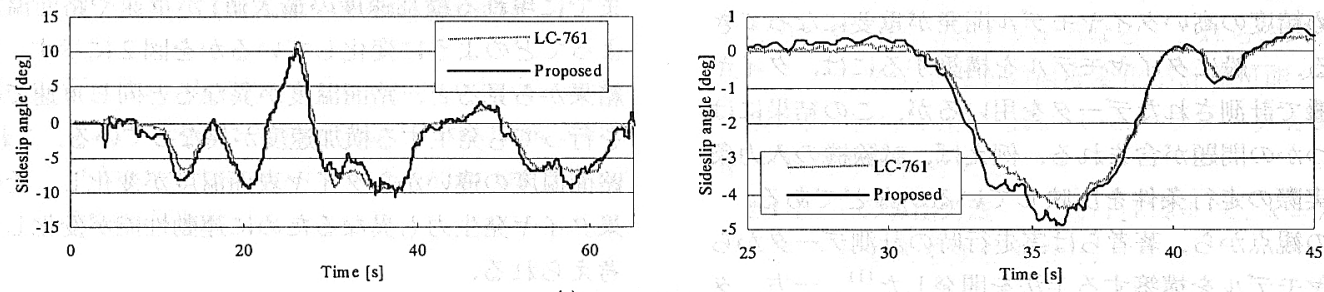

(d) Vehicle sideslip angle

Fig.10 Example of experiment

\section{文 献}

（1）例えば，日本機械学会，RC141 IIS-AVCS(知的交通システム における先進車両制御システム)に関する研究分科会研究 報告書, (1998)

（2）安部，自動車の運動之制御，山海堂，(2003）

（3）堀，電気と制御で走る近未来車両に関する研究，FEDレビ ュ一, Vol3, No.4, (2004)

（4）株式会社 小野測器, CL761 システムカタログ

（5）福庭，吉本，高橋，吉岡，GPSによる車体横滑り角計測技 術の開発，自動車技術会 2001 年春季学術講演前刷集, No.5-01, (2001)

（6）山口，浅野，天野，車体横すべり角推定法の開発，豊田中 央研究所R\&Dレビュー, Vol36, No.1, pp31-38, (2001)
（7）井上，﨩，車体横すべり角 $\beta$ を推定する線形オブザーバに 関する考察，計測制御学会第2回制御部門大会，pp29-31, (2002)

（8）神永，内藤，適応オブザーバを使用した車両の横滑り角推 定，自動車技術会 1998年春季学術講演前別集，№.982， pp.231-234, (1998)

（9）十川，缡，瀬田，ADA用ステレオ画像認識装置の開発，ス バル技報，Vol.27，pp29-35，(2000)

（10）岡田, 青山, 加賀美, 稲葉, 井上, 三次元フローを用いた 人込みにお汭るロボットの障害物回避、第5 回ロボティク スシンポジア予稿集, pp214-219, (2000)

（11）松山，久野，井宮，コンピュータビジョン: 技術評論と将 来展望，新技術コミュニケーションズ，pp123-137，(1998)

（12）菅沼, 藤井, 藤原，ステレオビジョンを用いた三次元路面 解析に基づく障害物検出, 第 3 回 IIS シンポジウム 2004 講 演論文集, pp301-306，(2005) 